\title{
OPTIMISATION OF THE ENZYME-ASSISTED EXTRACTION OF POLYPHENOLS FROM SAFFRON (CROCUS SATIVUS L.) TEPALS
}

\author{
Alexios Theodoros Vardakas ${ }^{1 凶}$, Vasil Todorov Shikov ${ }^{1}$, Rada Hristova Dinkova ${ }^{2}$, \\ Kiril Mihalev Mihalev²
}

${ }^{1}$ Preservation and Refrigeration Technology, University of Food Technologies Maritza Blvd 26, 4000 Plovdiv, Bulgaria

${ }^{2}$ Food Preservation and Refrigeration Technology, University of Food Technologies

Maritza Blvd 26, 4000 Plovdiv, Bulgaria

\begin{abstract}
Background. Saffron tepals are a by-product from the processing of Crocus sativus flowers, whose dried stigmas (saffron spice) are widely used both in the food and health sectors. Saffron tepals are rich in polyphenols, particularly flavonol glycosides and anthocyanins, which are considered to be potent antioxidants. Enzyme-assisted extraction of polyphenols offers several advantages in comparison to conventional methods. The present study evaluated the efficiency of enzyme-assisted extraction as a green technology for recovery of polyphenols from saffron tepals.

Materials and methods. The by-product was obtained from a saffron producer in the region of Kozani, Greece. A simplex-centroid design was applied to select the enzyme preparations mixture required for aqueous extraction of polyphenolic antioxidants from dried saffron tepals. In addition, the parameters of enzymatic hydrolysis, enzyme dose and incubation time were optimised using response surface methodology.

Results. The binary combination, comprising cellulolytic and hemicellulolytic preparations (1:1), led to the highest yield of total polyphenols (30.9 g GAE/ $/ \mathrm{kg}$ saffron tepals) and total anthocyanins ( $2.0 \mathrm{~g} \mathrm{CGE} / \mathrm{kg} \mathrm{saf-}$ fron tepals), reaching $45 \%$ and $38 \%$ higher values, respectively, as compared to the control sample (without enzymatic treatment). The experimental data regarding optimisation of the extraction conditions were fitted to second-degree regression models $\left(R^{2}=0.85-0.98\right)$.

Conclusion. The newly developed process may be applied as an environmentally friendly alternative to conventional organic solvent extraction, thus supporting valorisation of the saffron industry by-product. The polyphenols recovered could be used as biologically active substances or as natural food ingredients, replacing synthetic additives.
\end{abstract}

Keywords: plant by-product, antioxidants, green technology, enzyme preparation

\section{INTRODUCTION}

Plant by-products originating from the agri-food industry have been demonstrated to contain large amounts of valuable compounds that could be recovered and used as biologically active substances or as natural food ingredients, replacing synthetic additives (Schieber, 2017).
Saffron, Crocus sativus L., is systematically cultivated in Greece, Iran, Spain, Morocco and other countries for the use of its dried stigmas (saffron spice) in foods both for their intensive flavouring and colouring properties (Carmona et al., 2007). In addition, stigmas 
have also been shown to possess pharmacological properties, including activity on the nervous and cardiovascular systems and antidepressant, anxiolytic and antineoplastic effects (Bagur et al., 2018; Moratalla-López et al., 2019).

Since approximately 150000 flowers are needed to produce $1 \mathrm{~kg}$ of saffron spice (Goli et al., 2012), representing only $7 \%$ of the total weight of the flower (Serrano-Díaz et al., 2012), a large amount of by-product (mainly tepals) is generated. The presence of carbohydrates, proteins, dietary fiber and minerals (Serrano-Díaz et al., 2013), alkaloids and steroids (Kumar et al., 2011), carotenoid derivates (Goupy et al., 2013) and monoterpenoids ( $\mathrm{Li}$ et al., 2004) has been found in the tepals of Crocus sativus. Moreover, saffron tepals are rich in polyphenols, particularly flavonol glycosides and anthocyanins, which are considered to be potent antioxidants (Termentzi and Kokkalou, 2008; Tuberoso et al., 2016).

Kaempferol glycosides are the major flavonols in $C$. sativus tepals, the main compound being kaempferol 3-O-sophoroside (Goupy et al., 2013; Lakka et al., 2019). Using LC-MS, Goupy et al. (2013) identified delphinidin 3,7-O-diglucoside as the main anthocyanin, while Lakka et al. (2019) reported delphinidin 3,5-di- $O$-glucoside as the major compound.

Besides organic solvent extraction of polyphenols and anthocyanins from saffron tepals (Da Porto and Natolino, 2018; Mahdavee Khazaei et al., 2016), several green technologies, such as subcritical water extraction (Ahmadian-Kouchaksaraie et al., 2016) and use of a deep eutectic solvent (Lakka et al., 2019), have been proposed. To date, to the best of our knowledge, there is only one study (Lotfi et al., 2015) on enzyme-assisted extraction dealing solely with the recovery of anthocyanins.

Enzyme-assisted extraction of polyphenols offers several advantages in comparison to conventional methods: no environmental hazards due to the usage of flammable or volatile solvents; mild reaction conditions; processes requiring fewer steps, while also potentially lowering production costs by replacing multiple installations (Gligor et al., 2019). Commercially available enzyme preparations contain multiple activities which act on the plant cell wall, with different enzyme mixtures optimised for different substrates (Gama et al., 2015).
As there are no tailor-made enzyme mixtures for saffron tepal processing, the present study investigated combinations of preparations which together would contain the enzymes required for cell wall degradation. In addition, the parameters of enzymatic hydrolysis, enzyme dose and incubation time were optimised for recovery of total polyphenols and total anthocyanins using response surface methodology.

\section{MATERIALS AND METHODS}

\section{Plant material}

Saffron (Crocus sativus L.) tepals, harvest year 2019, were obtained from a producer in the region of Kozani, Greece. The tepals were dried at room temperature $\left(25-27^{\circ} \mathrm{C}\right)$ for one week before final hot air drying $\left(60^{\circ} \mathrm{C}, 1 \mathrm{~h}\right)$. Dried saffron tepals were stored in plastic bags at room temperature until used. The moisture content of the dried tepals was $9.4 \%(\mathrm{w} / \mathrm{w})$.

\section{Chemicals}

For analytical purposes, the following reagents were used: DPPH [2,2-diphenyl-1-picrylhydrazyl] and Trolox [(+/-)-6-hydroxy-2,5,7,8-tetramethyl-chroman-2-carboxylic acid] (Sigma-Aldrich, Steinheim, Germany); TPTZ [2,4,6-tripyridyl-s-triazine] and gallic acid monohydrate (Fluka, Buchs, Switzerland); Folin-Ciocalteau's reagent (Merck, Darmstadt, Germany). All the other reagents and solvents used were of analytical grade.

\section{Enzyme preparations}

The following commercial enzyme preparations were used: pectinolytic preparation Pectinex Ultra Color and cellulolytic preparation Celluclast BG (both form Novozymes A/S, Bagsvaerd, Denmark); hemicellulolytic preparation Xylanase AN (Biovet JSC, Peshtera, Bulgaria).

\section{Enzyme-assisted extraction}

Finely ground (particle size $<700 \mu \mathrm{m}$ ) saffron tepals were mixed with water $(10: 1, \mathrm{v} / \mathrm{w})$, acidified $(\mathrm{pH} 4.0)$ with $\mathrm{HCl}$, and left for $1 \mathrm{~h}$ for rehydration at $25^{\circ} \mathrm{C}$. After $\mathrm{pH}$ adjustment ( $\mathrm{pH} 4.0)$, the suspension (100.0 g) was placed in a $50^{\circ} \mathrm{C}$ water bath (W3, VEB MLW Prüfgeräte-Werk Medingen, Sitz Freital, Germany) for $20 \mathrm{~min}$ before $10 \mathrm{~mL}$ of an acidified water solution 
of enzyme preparation was added. After incubation at $50^{\circ} \mathrm{C}$, the sample was placed in a boiling water bath for $10 \mathrm{~min}$ to inactivate the enzymes, then immediately cooled in an ice bath and centrifuged $(4200 \mathrm{~g} \times$ $\left.15 \mathrm{~min}, 25^{\circ} \mathrm{C}\right)$. The supernatant obtained was filtered through a paper filter and weighed to determine the extract yield.

\section{Sample preparation}

An aliquot $(5 \mathrm{~mL})$ of filtered extract was transferred into a $50 \mathrm{~mL}$ volumetric flask using $40 \mathrm{ml}$ of acidified $(0.1 \% \mathrm{HCl})$ methanol. After sitting for $24 \mathrm{~h}$ at $10^{\circ} \mathrm{C}$, the flask was filled up to the mark with acidified methanol and filtered through a paper filter. Samples were prepared in triplicate.

\section{Phytochemical analyses}

All measurements were performed with a Helios Omega UV-Vis spectrophotometer equipped with VISIONlite software (all from Thermo Fisher Scientific Inc., Waltham, MA, USA) using $1 \mathrm{~cm}$ pathlength cuvettes.

The content of total polyphenols (TPP) was determined using the method of Singleton and Rossi (1965) in the following modification: an appropriately diluted sample solution $(0.1 \mathrm{~mL})$ was mixed with $0.5 \mathrm{~mL}$ of FC-reagent (diluted with distilled water 1:4, v/v) and $1.5 \mathrm{~mL}$ of sodium carbonate solution $(7.5 \%, \mathrm{w} / \mathrm{v})$ and the volume was made up to $10 \mathrm{~mL}$ with distilled water; the mixture was incubated for $2 \mathrm{~h}$ at room temperature before the absorbance was measured at $750 \mathrm{~nm}$. The results were presented as equivalents of gallic acid (GAE).

The amount of total monomeric anthocyanins (TMA) was determined using the pH-differential method (Giusti and Wrolstad, 2001). The sample solution was diluted in parallel with buffer $\mathrm{pH} 1.0(0.025 \mathrm{M}$ potassium chloride) and buffer $\mathrm{pH} 4.5$ (0.4 M sodium acetate). After $1 \mathrm{~h}$ of incubation at room temperature, the absorbance was measured at 520 and $700 \mathrm{~nm}$. The results were calculated using a molar extinction coefficient of $26900 \mathrm{~L} / \mathrm{mol} \cdot \mathrm{cm}$ and molecular weight of $449.2 \mathrm{~g} / \mathrm{mol}$ (Moyer et al., 2002) and expressed as equivalents of cyanidin 3-glucoside (CGE).

The total antioxidant capacity was determined using the DPPH (free radical scavenging activity) and FRAP (ferric reducing antioxidant power) assays. Trolox, a water-soluble vitamin E analogue, was used as a reference in both assays and the antioxidant capacity was expressed as equivalents of Trolox (TE).

DPPH assay was based on the method of Brand-Williams et al. (1995) modified as follows: $2250 \mu \mathrm{L}$ of a DPPH methanolic solution $\left(6 \times 10^{-5} \mathrm{M}\right)$ was mixed with $250 \mu \mathrm{L}$ of sample solution (diluted with distilled water $1: 3, \mathrm{v} / \mathrm{v}$ ); absorbance was measured at $515 \mathrm{~nm}$ after $15 \mathrm{~min}$ of reaction in a cap-sealed cuvette kept in the dark at room temperature.

FRAP assay was performed according to Benzie and Strain (1996) with some modifications. The FRAP reagent was prepared by mixing $2.5 \mathrm{~mL}$ of a TPTZ solution $(10 \mathrm{mmol} / \mathrm{L})$ in hydrochloric acid $(40 \mathrm{mmol} / \mathrm{L})$, $2.5 \mathrm{~mL}$ of a $\mathrm{FeCl}_{3}$ water solution $(20 \mathrm{mmol} / \mathrm{L})$ and 25 $\mathrm{mL}$ of an acetate buffer $(0.3 \mathrm{~mol} / \mathrm{L}, \mathrm{pH} 3.6)$. In the assay, $2250 \mu \mathrm{L}$ of FRAP reagent and $250 \mu \mathrm{L}$ of sample solution (diluted with distilled water $1: 3, \mathrm{v} / \mathrm{v}$ ) were mixed in a cuvette and absorbance was measured at $593 \mathrm{~nm}$ after $4 \mathrm{~min}$ of reaction.

\section{Experimental design}

According to Kalcheva-Karadzhova et al. (2014), a simplex-centroid design for a mixture with three components was applied (Fig. 1). Enzyme preparations (single or mix) were used as $1.2 \%(\mathrm{v} / \mathrm{v})$ solution and the incubation time was $120 \mathrm{~min}$.

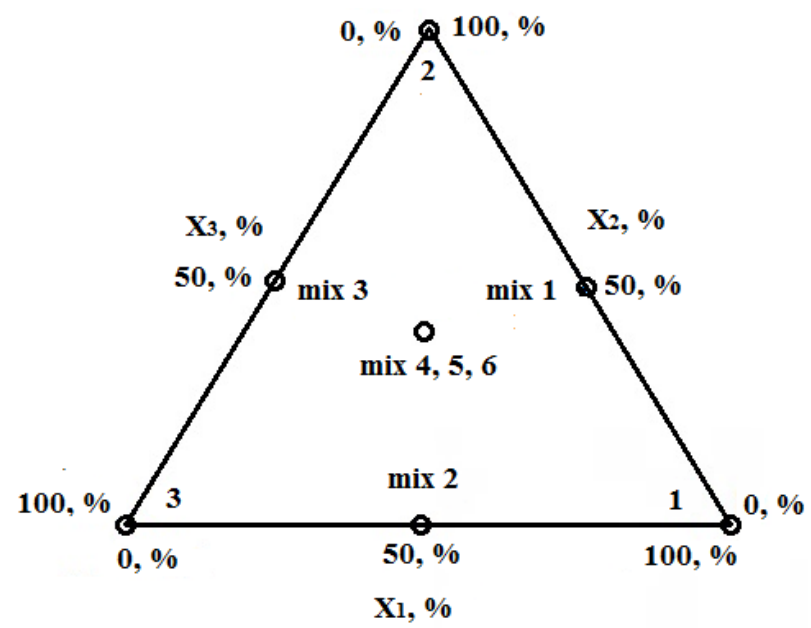

Fig. 1. Ternary diagram for the simplex-centroid design: $1-$ $100 \%$ Pectinex Ultra Color $\left(X_{1}\right), 2-100 \%$ Celluclast BG $\left(X_{2}\right), 3-100 \%$ Xylanase $\mathrm{AN}\left(X_{3}\right), \operatorname{mix} 1-X_{1}: X_{2}=1: 1 ; \operatorname{mix} 2-$ $X_{1}: X_{3}=1: 1 ; \operatorname{mix} 3-X_{2}: X_{3}=1: 1 ; \operatorname{mix} 4,5,6-X_{1}: X_{2}: X_{3}=1: 1: 1$ 
An optimal central composite design (OCCD) of type $2^{n}+2 n+n_{0}$ was applied. The influence of the independent variables was determined by means of the response surface methodology (Kalcheva-Karadzhova et al., 2016). Table 1 shows the levels of the two independent variables - enzyme dose $(0.02-0.18 \%)$ and reaction time $(30-210 \mathrm{~min})$. The enzyme used was a 1:1 mixture of the cellulolytic and hemicellulolytic preparations. The experimental data were fitted to a second-degree regression equation:

$$
y=b_{0}+\sum_{i=1}^{n} b_{i} x_{i}+\sum_{i=1}^{n} b_{\mathrm{ii}} \mathrm{x}_{i}^{2}+\sum_{i=1}^{n} \sum_{j=1}^{n} b_{\mathrm{ij}} x_{i} x_{j}
$$

where:

$$
\begin{array}{ll}
y & - \text { the dependent variable (response), } \\
b_{0} & \text { - the model intercept, } \\
b_{i}, b_{\mathrm{ii}}, b_{\mathrm{ij}} & \text { - the linear, quadratic, and interaction re- } \\
& \text { gression coefficients, respectively, } \\
x_{i}, x_{j} & \text { - the independent variables, } \\
n & \text { - equal to the number of the tested factors } \\
& (n=2 \text { in this study). }
\end{array}
$$

Table 1. Values of the independent variables at the corresponding levels

\begin{tabular}{lcccc}
\hline \multicolumn{1}{c}{ Factor } & Minima & Center point & Maxima & Axial point \\
\hline Enzyme dose & 0.02 & 0.1 & 0.18 & $-\alpha=-1$ \\
$X_{1}, \%$ E/S* & & & & $+\alpha=+1$ \\
& & & & \\
Time $X_{2}$, min & 30 & 120 & 210 & $-\alpha+=-1$ \\
& & & & $+\alpha=+1$
\end{tabular}

* Grams of enzyme mixture per $100 \mathrm{~g}$ of substrate (suspension).

\section{Statistical analysis}

The results reported in the present study are the mean values of at least three analytical determinations, and the coefficients of variation expressed as the percentage ratios between the standard deviations and the mean values were found to be $<5 \%$ in all cases. The means were compared using one-way ANOVA and Tukey's test at a $95 \%$ confidence level.

\section{RESULTS AND DISCUSSION}

\section{Selection of the mixture of enzyme preparations}

Significant increases in the recovery rates of total polyphenols and total anthocyanins were observed due to the enzymatic treatments (Table 2, Fig. $2 a$ and $2 b$ ).

The binary combination containing cellulolytic and hemicellulolytic preparations $\left(X_{2}: X_{3}=1: 1\right)$ resulted in the highest yield of total polyphenols, reaching a $45 \%$ higher value as compared to the control sample (without enzymatic treatment). This value (30.9 g GAE $/ \mathrm{kg}$ saffron tepals) is higher than that $(3.4 \mathrm{~g} \mathrm{GAE} / \mathrm{kg})$ reported for methanolic extract (Goli et al., 2012), but lower than that (112.2 g GAE $/ \mathrm{kg}$ ) obtained for $60 \%$ ethanolic extract (Lakka et al., 2019). However, possible differences in the polyphenolic content of the raw materials should be taken into account.

The yield of total anthocyanins was $38 \%$ higher due to the enzymatic treatment. This value $(2.0 \mathrm{~g} \mathrm{CGE} / \mathrm{kg}$ saffron tepals) is lower than that $(6.7 \mathrm{~g} \mathrm{CGE} / \mathrm{kg})$ reported by Lotfi et al. (2015), which could be attributed to the different raw materials and enzyme preparations used.

Consistent with Østby et al. (2020), these results confirm the co-operativity between cellulases and hemicellulases in the enzymatic hydrolysis of lignocellulosic cell wall material.

Interestingly, similar effects with respect to the total polyphenols and total anthocyanins were observed for the pectinolytic and cellulolytic preparations mixture $\left(X_{1}: X_{2}=1: 1\right)$, which is probably due to the secondary xylanase activity of commercial pectinase (Kalcheva-Karadzhova et al., 2014).

The two assays used represent different mechanisms for evaluating antioxidant capacity. While the DPPH assay measures the ability of plant extracts to scavenge free radicals, the FRAP assay quantifies the total concentration of redox-active compounds (Magalhães et al., 2008). In general, the changes in the total antioxidant capacity (Table 2, Fig. 2c and 2d) correspond to the results obtained for the total polyphenols.

\section{Optimisation of the process parameters}

Significant variations in the yields of total polyphenols and total anthocyanins were observed in response to the different enzymatic treatments (Table 3). 
Vardakas, A. T., Shikov, V. T., Dinkova, R. H., Mihalev, K. M. (2021). Optimisation of the enzyme-assisted extraction of polyphenols from saffron (Crocus sativus L.) tepals. Acta Sci. Pol. Technol. Aliment., 20(3), 359-367. http://dx.doi.org/10.17306/J.AFS.2021.0954

Table 2. Treatment variants and results ${ }^{1}$ for the simplex-centroid design

\begin{tabular}{|c|c|c|c|c|c|}
\hline Variant & $\begin{array}{c}\text { Extract yield } \\
\%\end{array}$ & $\begin{array}{c}\text { TPP }^{2} \\
\text { g GAE/kg }\end{array}$ & $\begin{array}{c}\mathrm{TMA}^{3} \\
\text { g CGE/kg }\end{array}$ & $\begin{array}{c}\mathrm{DPPH}^{4} \\
\mu \mathrm{mol} \mathrm{TE} / \mathrm{kg}\end{array}$ & $\begin{array}{c}\text { FRAP }^{4} \\
\mu \mathrm{mol} \mathrm{TE} / \mathrm{kg}\end{array}$ \\
\hline Control (no enzyme) & 58.96 & $21.32 \pm 1.07 \mathrm{a}$ & $1.45 \pm 0.07 \mathrm{ab}$ & $35.89 \pm 1.80 \mathrm{a}$ & $63.15 \pm 3.16 \mathrm{ab}$ \\
\hline 1 & 60.40 & $22.16 \pm 1.11 \mathrm{ad}$ & $1.51 \pm 0.08 \mathrm{a}$ & $41.83 \pm 2.09 b c$ & $62.05 \pm 3.10 \mathrm{a}$ \\
\hline 2 & 62.40 & $22.96 \pm 1.15 \mathrm{ad}$ & $1.34 \pm 0.07 \mathrm{~b}$ & $40.40 \pm 2.02 b$ & $61.62 \pm 3.08 \mathrm{a}$ \\
\hline 3 & 69.52 & $26.83 \pm 1.34 b$ & $1.47 \pm 0.07 \mathrm{ab}$ & $45.06 \pm 2.26 \mathrm{c}$ & $73.72 \pm 3.69 b$ \\
\hline Mix 1 & 79.63 & $30.23 \pm 1.51 \mathrm{ce}$ & $2.00 \pm 0.10 \mathrm{c}$ & $51.06 \pm 2.56 \mathrm{~d}$ & $91.00 \pm 4.55 c$ \\
\hline Mix 2 & 61.78 & $24.20 \pm 1.21 \mathrm{~d}$ & $1.51 \pm 0.08 \mathrm{a}$ & $40.26 \pm 2.02 b$ & $69.93 \pm 3.50 \mathrm{~b}$ \\
\hline Mix 3 & 79.56 & $30.90 \pm 1.55 c$ & $2.00 \pm 0.10 \mathrm{c}$ & $53.45 \pm 2.66 \mathrm{~d}$ & $91.41 \pm 4.57 \mathrm{c}$ \\
\hline $\operatorname{Mix} 4,5,6$ & 77.73 & $28.30 \pm 1.42 \mathrm{be}$ & $1.86 \pm 0.09 \mathrm{c}$ & $43.33 \pm 2.17 b c$ & $89.30 \pm 4.47 \mathrm{c}$ \\
\hline
\end{tabular}

${ }^{1}$ Means \pm standard deviation $(n=3)$. Different letters within a column indicate significant differences (Tukey's test, $P<0.05$ ).

${ }^{2}$ Results are expressed as grams of gallic acid equivalents (GAE) per $1 \mathrm{~kg}$ saffron tepals (dry weight basis, dwb).

${ }^{3}$ Results are expressed as grams of cyaniding 3-glucoside equivalents (CGE) per $1 \mathrm{~kg}$ saffron tepals (dwb).

${ }^{4}$ Results are expressed as micromoles of Trolox equivalents (TE) per $1 \mathrm{~kg}$ saffron tepals (dwb).
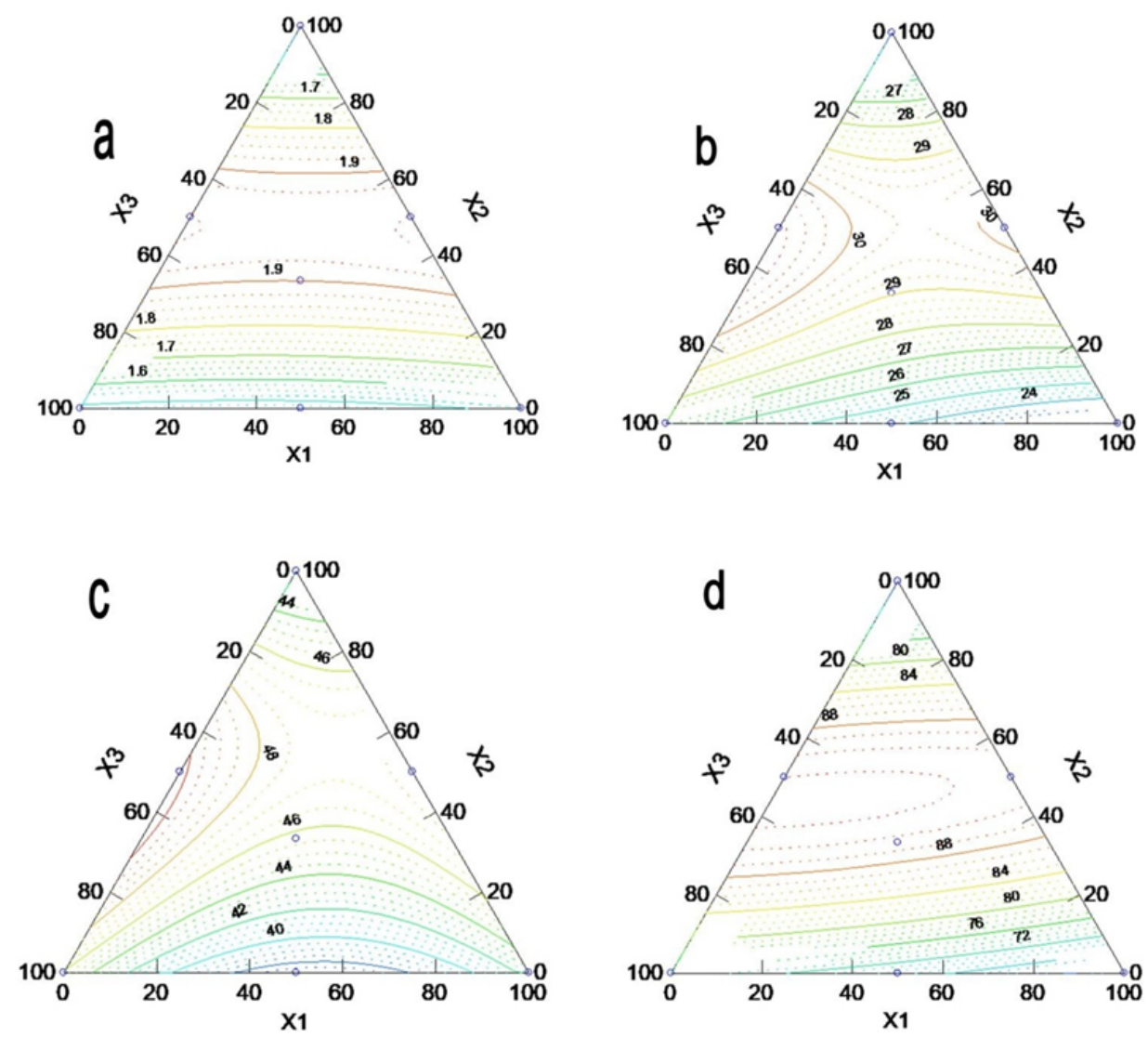

Fig. 2. Simplex contour plots for: $\mathrm{a}-\mathrm{TMA}, \mathrm{b}-\mathrm{TPP}, \mathrm{c}-\mathrm{DPPH}, \mathrm{d}-\mathrm{FRAP}$ 
Vardakas, A. T., Shikov, V. T., Dinkova, R. H., Mihalev, K. M. (2021). Optimisation of the enzyme-assisted extraction of polyphenols from saffron (Crocus sativus L.) tepals. Acta Sci. Pol. Technol. Aliment., 20(3), 359-367. http://dx.doi.org/10.17306/J.AFS.2021.0954

Table 3. Experimental design matrix and results ${ }^{1}$ for the optimal central composite design

\begin{tabular}{|c|c|c|c|c|c|c|c|c|c|}
\hline \multirow[t]{2}{*}{ No } & \multirow{2}{*}{\multicolumn{2}{|c|}{$\begin{array}{l}\text { Coded } \\
\text { values }\end{array}$}} & $\begin{array}{c}\text { Enzyme dose } \\
\% \mathrm{E} / \mathrm{S}^{2}\end{array}$ & $\begin{array}{l}\text { Time } \\
\min \end{array}$ & $\begin{array}{c}\text { TMA }^{3} \\
\text { g CGE/kg }\end{array}$ & $\begin{array}{c}\mathrm{TPP}^{4} \\
\text { g GAE/kg }\end{array}$ & $\begin{array}{c}\mathrm{DPPH}^{5} \\
\mu \mathrm{mol} \mathrm{TE} / \mathrm{kg}\end{array}$ & $\begin{array}{c}\text { FRAP }^{5} \\
\mu \mathrm{mol} \mathrm{TE} / \mathrm{kg}\end{array}$ & $\begin{array}{c}\text { Extract yield } \\
\%\end{array}$ \\
\hline & & & $X_{1}$ & $X_{2}$ & $Y_{1}$ & $Y_{2}$ & $Y_{3}$ & $Y_{4}$ & $Y_{5}$ \\
\hline 1 & - & - & 0.02 & 30 & $0.22 \pm 0.01 \mathrm{a}$ & $7.30 \pm 0.37 \mathrm{a}$ & $19.10 \pm 0.96 a$ & $31.04 \pm 1.55 \mathrm{a}$ & 46.03 \\
\hline 2 & + & - & 0.18 & 30 & $0.19 \pm 0.01 b$ & $7.98 \pm 0.40 \mathrm{a}$ & $16.56 \pm 0.83 b$ & $35.78 \pm 1.79 b f$ & 47.67 \\
\hline 3 & - & + & 0.02 & 210 & $0.23 \pm 0.01 \mathrm{a}$ & $8.52 \pm 0.43 a$ & $22.13 \pm 1.11 \mathrm{c}$ & $38.41 \pm 1.92 \mathrm{cf}$ & 51.87 \\
\hline 4 & + & + & 0.18 & 210 & $0.43 \pm 0.02 \mathrm{ci}$ & $24.96 \pm 1.25 b$ & $25.20 \pm 1.26 \mathrm{de}$ & $45.22 \pm 2.26 \mathrm{~d}$ & 59.64 \\
\hline 5 & - & 0 & 0.02 & 120 & $0.31 \pm 0.02 \mathrm{~d}$ & $20.28 \pm 1.01 \mathrm{c}$ & $22.18 \pm 1.11 \mathrm{c}$ & $34.67 \pm 1.73 b$ & 49.79 \\
\hline 6 & + & 0 & 0.18 & 120 & $0.38 \pm 0.02 \mathrm{eh}$ & $22.86 \pm 1.14 \mathrm{de}$ & $22.91 \pm 1.15 c$ & $36.59 \pm 1.83 \mathrm{bg}$ & 55.49 \\
\hline 7 & 0 & - & 0.1 & 30 & $0.34 \pm 0.02 \mathrm{f}$ & $21.48 \pm 1.07 \mathrm{~cd}$ & $25.38 \pm 1.27 \mathrm{de}$ & $38.41 \pm 1.92 \mathrm{cfg}$ & 50.67 \\
\hline 8 & 0 & + & 0.1 & 210 & $0.40 \pm 0.02 \mathrm{e}$ & $24.46 \pm 1.22 b$ & $26.67 \pm 1.33 \mathrm{~d}$ & $39.62 \pm 1.98 \mathrm{ce}$ & 56.29 \\
\hline 9 & 0 & 0 & 0.1 & 120 & $0.47 \pm 0.02 \mathrm{~g}$ & $22.40 \pm 1.12 \mathrm{de}$ & $26.72 \pm 1.34 \mathrm{~d}$ & $41.90 \pm 2.10 \mathrm{eh}$ & 53.91 \\
\hline 10 & 0 & 0 & 0.1 & 120 & $0.45 \pm 0.02 \mathrm{gi}$ & $23.90 \pm 1.20 \mathrm{be}$ & $26.55 \pm 1.33 \mathrm{~d}$ & $43.70 \pm 2.19 \mathrm{dh}$ & 54.23 \\
\hline 11 & 0 & 0 & 0.1 & 120 & $0.37 \pm 0.02 \mathrm{~h}$ & $21.35 \pm 1.07 \mathrm{~cd}$ & $23.79 \pm 1.19 \mathrm{ce}$ & $34.13 \pm 1.71 b$ & 57.39 \\
\hline
\end{tabular}

${ }^{1}$ Means \pm standard deviations $(n=3)$. Different letters within a column indicate significant differences (Tukey’s test, $P<0.05$ ).

${ }^{2}$ Grams of enzyme mixture per $100 \mathrm{~g}$ substrate (suspension).

${ }^{3}$ Results are expressed as grams of cyaniding 3-glucoside equivalents (CGE) per $1 \mathrm{~kg}$ saffron tepals (dry weight basis, dwb).

${ }^{4}$ Results are expressed as grams of gallic acid equivalents (GAE) per $1 \mathrm{~kg}$ saffron tepals (dwb).

${ }^{5}$ Results are expressed as micromoles of Trolox equivalents (TE) per $1 \mathrm{~kg}$ saffron tepals (dwb).

In accordance with Lotfi et al. (2015), with an increase in the enzyme dose, the recovery rate of total anthocyanins increased until the middle of the experiment and afterwards started to decline. The negative effects of the higher enzyme dose indicate that the preparations might possess secondary enzyme activities that catalyse the degradation of anthocyanins. Indeed, the presence of some glycosidases would cause deglycosylation of the anthocyanidin glycosides, which in turn results in unstable aglycons (Wrolstad et al., 1994).

The positive effects of incubation time on the total polyphenol yield imply that extensive enzymatic cell wall digestion promotes releasing of insoluble-bound phenolic compounds (Wang et al., 2017).

The experimental data in Table 3 were used to determine the coefficients of four second-order polynomial equations as follows:

$$
\begin{gathered}
Y_{1}=0.117+2.93 X_{1}+0.00225 X_{2}-16.9 X_{1}^{2}+ \\
0.00799 X_{1} X_{2}-0.0000103 X_{2}^{2}, \mathrm{~g} \mathrm{CGE} / \mathrm{kg} \\
R^{2}=0.98
\end{gathered}
$$

$$
\begin{gathered}
Y_{2}=3.88+176.1 X_{1}+0.133 X_{2}-1003.5 X_{1}^{2}+ \\
0.547 X_{1} X_{2}-0.00062 X_{2}^{2}, \mathrm{~g} \mathrm{GAE} / \mathrm{kg}, \\
R^{2}=0.85 \\
Y_{3}=16.5+126.6 X_{1}+0.0411 X_{2}-736.6 X_{1}^{2}+ \\
0.195 X_{1} X_{2}-0.000152 X_{2}^{2}, \mathrm{~g} \mathrm{TE} / \mathrm{kg}, \\
R^{2}=0.93 \\
Y_{4}=26.4+197.4 X_{1}+0.0434 X_{2}-861.5 X_{1}^{2}- \\
0.0226 X_{1} X_{2}-0.0000233 X_{2}^{2}, \mathrm{~g} \mathrm{TE} / \mathrm{kg}, \\
R^{2}=0.94
\end{gathered}
$$

where:

$Y_{1}, Y_{2}, Y_{3}, Y_{4}$ - the predicted responses for TMA, TPP, DPPH and FRAP, respectively,

$X_{1}$ - the enzyme dose,

$X_{2}$ - the incubation time.

All of the $R^{2}$ (coefficient of determination) values were greater than 0.80 , implying that the models accurately represent the experimental data (Iglesias-Carres et al., 2018).

Both the incubation time and enzyme dose produced positive linear and negative quadratic effects on total 
Vardakas, A. T., Shikov, V. T., Dinkova, R. H., Mihalev, K. M. (2021). Optimisation of the enzyme-assisted extraction of polyphenols from saffron (Crocus sativus L.) tepals. Acta Sci. Pol. Technol. Aliment., 20(3), 359-367. http://dx.doi.org/10.17306/J.AFS.2021.0954

anthocyanins and total polyphenols. This means that the yields of total anthocyanins (Fig. 3a) and total polyphenols (Fig. 3b) increase when the incubation time or enzyme dose increases up to a certain point, after which they begin to decrease. Positive linear and negative quadratic effects of incubation time were also reported for total polyphenols and total anthocyanins in extracts from rose petals (Kalcheva-Karadzhova et al., 2016).

Positive linear effects of incubation time and negative quadratic effects of enzyme dose were obtained for the total antioxidant capacity values (Fig. 3c-3d), suggesting similar changes to those observed for the total polyphenols.

A graphical optimisation of the extraction conditions was carried out in order to maximise the yields of total polyphenols and total anthocyanins. Figure 4 shows the overlapping region, defining the intervals of variation of the enzyme mixture dose $(0.12-0.15 \%)$ and treatment time (145-185 min) that satisfy the optimisation criterion.
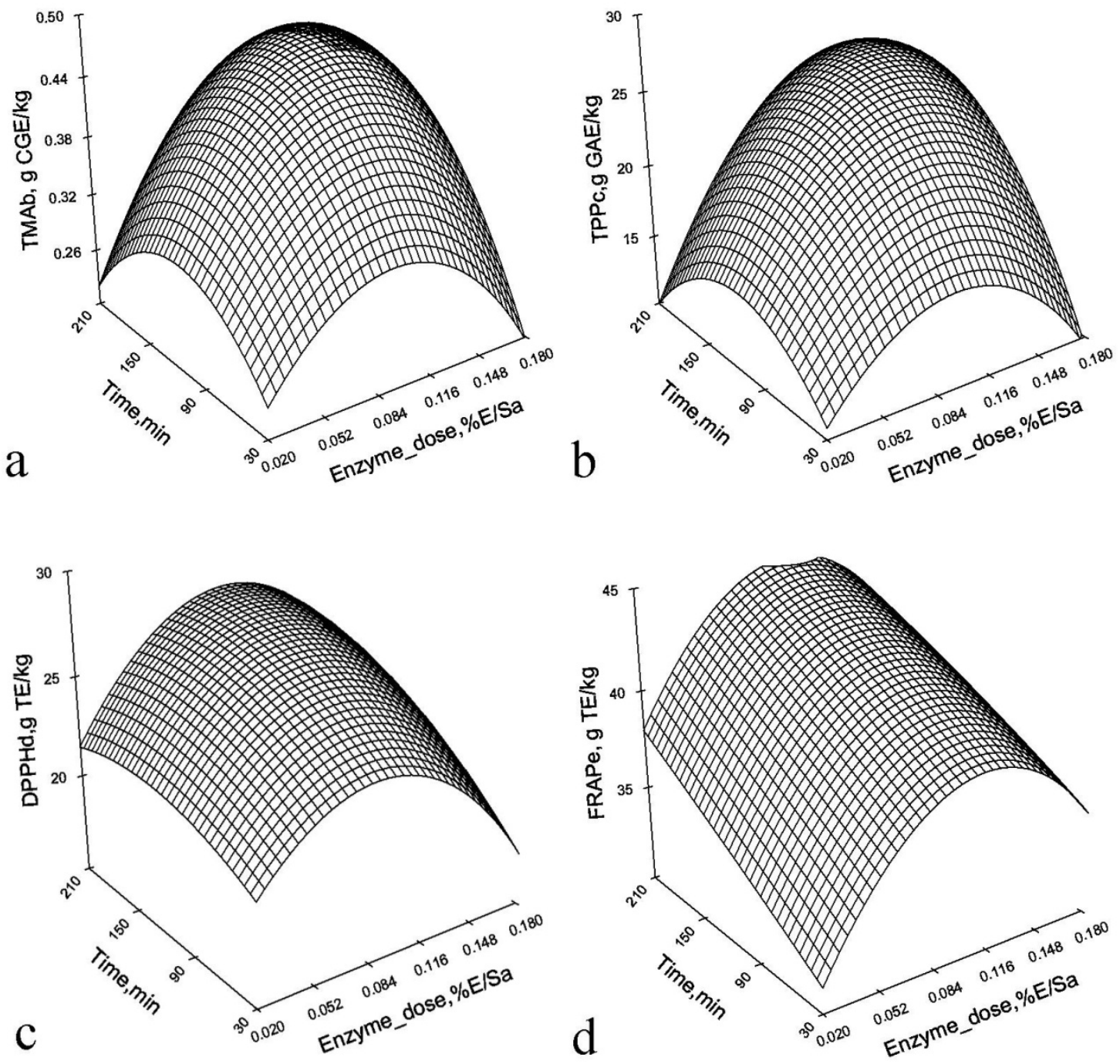

Fig. 3. Response surfaces showing the effects of enzyme mixture dose, $\% \mathrm{E} / \mathrm{Sa}$ - grams of enzyme mixture per $100 \mathrm{~g}$ substrate, and incubation time, min, on: a - TMA, b - TPP, c - DPPH, d - FRAP 


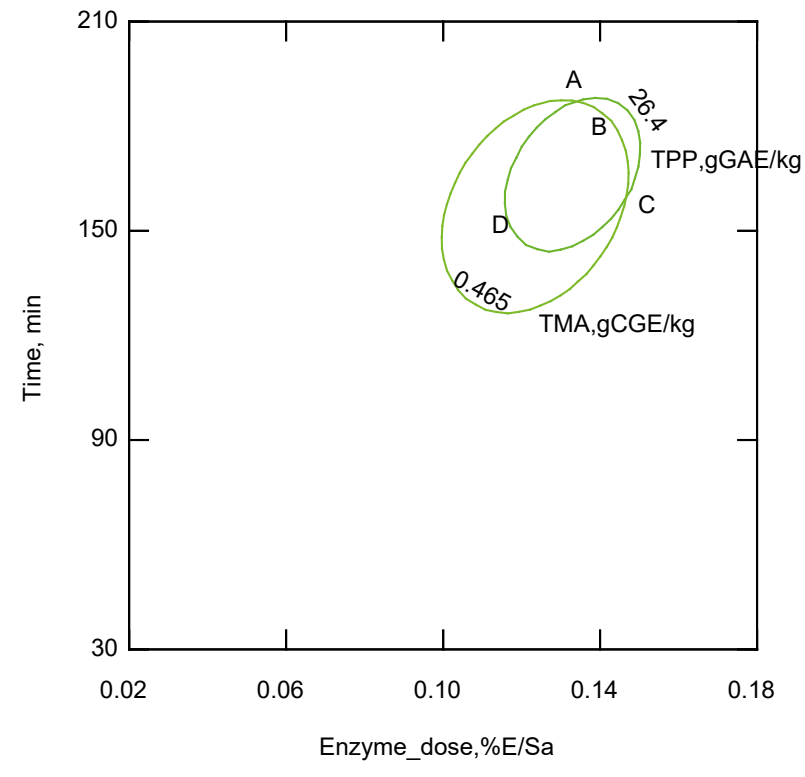

Fig. 4. Graphical optimisation of the extraction conditions - enzyme mixture dose, \% $\mathrm{E} / \mathrm{Sa}$ - grams of enzyme mixture per $100 \mathrm{~g}$ substrate, and incubation time, $\min$

\section{CONCLUSION}

The results obtained demonstrate that the enzyme-assisted extraction enhances the recovery of polyphenolic antioxidants from saffron tepals, especially using the binary enzyme combination comprising cellulolytic and hemicellulolytic preparations $(1: 1)$. The intervals of variation of the enzyme mixture dose $(0.12-0.15 \%)$ and incubation time (145-185 $\mathrm{min})$ define the optimal region for obtaining extracts with high yields of both total polyphenols and total anthocyanins. This new process can be considered to be a green technology, offering an environmentally friendly alternative to conventional organic solvent extraction.

\section{REFERENCES}

Ahmadian-Kouchaksaraie, Z., Niazmand, R., Najafi, M. N. (2016). Optimization of the subcritical water extraction of phenolic antioxidants from Crocus sativus petals of saffron industry residues: Box-Behnken design and principal component analysis. Innov. Food Sci. Emer. Technol., 36, 234-244.

Bagur, M. J., Alonso Salinas, G. L., Jiménez-Monreal, A. M., Chaouqi, S., Llorens, S., Martínez-Tomé, M.,
Alonso, G. L. (2018). Saffron: An old medicinal plant and a potential novel functional food. Molecules, 23, 30. http://dx.doi.org/10.3390/molecules 23010030

Benzie, I. F. F., Strain, J. J. (1996). The ferric reducing ability of plasma (FRAP) as a measure of "antioxidant power": The FRAP assay. Anal. Biochem., 239, 70-76. https://doi.org/10.1006/abio.1996.0292

Brand-Williams, W., Cuvelier, M. E., Berset, C. (1995). Use of a free radical method to evaluate antioxidant activity. LWT - Food Sci. Technol., 28, 25-30. https://doi. org/10.1016/S0023-6438(95)80008-5

Carmona, M., Sánchez, A. M., Ferreres, F., Zalacain, A., Tomás-Barberán, F., Alonso, G. L. (2007). Identification of the flavonoid fraction in saffron spice by LC/DAD/ MS/MS: Comparative study of samples from different geographical origins. Food Chem., 100, 445-450.

Da Porto, C., Natolino, A. (2018). Extraction kinetic modelling of total polyphenols and total anthocyanins from saffron floral bio-residues: Comparison of extraction methods. Food Chem., 258,137-143.

Gama, R., Van Dyk, J. S., Pletschke, B. I. (2015). Optimisation of enzymatic hydrolysis of apple pomace for production of biofuel and biorefinery chemicals using commercial enzymes. 3 Biotech, 5, 1075-1087.

Giusti, M. M., Wrolstad, R. E. (2001). Characterization and measurement of anthocyanins by UV-visible spectroscopy. In R. E. Wrolstad (Ed.), Current protocols in food analytical chemistry (pp. F1.2.1-F1.2.13). New York: Wiley.

Gligor, O., Mocan, A., Moldovan, C., Locatelli, M., Crișan, G., Ferreira, I. C. F. R. (2019). Enzyme-assisted extractions of polyphenols - A comprehensive review. Trends Food Sci. Technol., 88, 302-315.

Goli, S. A. H., Mokhtari, F., Rahimmalek, M. (2012). Phenolic compounds and antioxidant activity from saffron (Crocus sativus L.) petal. J. Agric. Sci., 4, 175-181.

Goupy, P., Vian, M. A., Chemat, F., Caris-Veyrata, C. (2013). Identification and quantification of flavonols, anthocyanins and lutein diesters in tepals of Crocus sativus by ultra performance liquid chromatography coupled to diode array and ion trap mass spectrometry detections. Ind. Crops Prod., 44, 496-510. https://doi.org/10.1016/j. indcrop.2012.10.004

Iglesias-Carres, L., Mas-Capdevila, A., Sancho-Pardo, L., Bravo, F. I., Mulero, M., Muguerza, B., Arola-Arnal, A. (2018). Optimized extraction by response surface methodology used for the characterization and quantification of phenolic compounds in whole red grapes (Vitis vinifera). Nutrients, 10(12), 1931. https://doi.org/10.3390/ nu10121931 
Vardakas, A. T., Shikov, V. T., Dinkova, R. H., Mihalev, K. M. (2021). Optimisation of the enzyme-assisted extraction of polyphenols from saffron (Crocus sativus L.) tepals. Acta Sci. Pol. Technol. Aliment., 20(3), 359-367. http://dx.doi.org/10.17306/J.AFS.2021.0954

Kalcheva-Karadzhova, K. D., Mihalev, K. M., Ludneva, D. P., Shikov, V. T., Dinkova, R. H., Penov, N. D. (2016). Optimizing enzymatic extraction from rose petals (Rosa damascena Mill.). Bulg. Chem. Comm., 48, 459-463.

Kalcheva-Karadzhova, K., Shikov, V., Mihalev, K., Dobrev, G., Ludneva, D., Penov, N. (2014). Enzyme-assisted extraction of polyphenols from rose (Rosa damascena Mill.) petals. Acta Univ. Cibin. Ser. E: Food Technol., 18, 65-72. https://doi.org/10.2478/aucft-2014-0015

Kumar, V., Bhat, Z. A., Kumar, D., Shah, M. Y., Chashoo, I. A., Khan, N. A. (2011). Physicochemical and preliminary phytochemical studies on petals of Crocus sativus 'Cashmerianus'. Pharmacogn. J., 23, 46-49.

Lakka, A., Grigorakis, S., Karageorgou, I., Batra, G., Kaltsa, O., Bozinou, E., ..., Makris, D. P. (2019). Saffron processing wastes as a bioresource of high-value added compounds: Development of a green extraction process for polyphenol recovery using a natural deep eutectic solvent. Antioxidants, 8, 586. https://doi.org/10.3390/ antiox8120586

Li, C.-Y., Lee, E.-J., Wu, T.-S. (2004). Antityrosinase principles and constituents of the petals of Crocus sativus. J. Nat. Prod., 67, 437-440.

Lotfi, L., Kalbasi-Ashtari, A., Hamedi, M., Ghorbani, F. (2015). Effects of enzymatic extraction on anthocyanins yield of saffron tepals (Crocos sativus) along with its color properties and structural stability. J. Food Drug Anal., 23, 210-218. https://doi.org/10.1016/j. jfda.2014.10.011

Magalhães, L. M., Segundo, M. A., Reis, S., Lima, J. L. F. C. (2008). Methodological aspects about in vitro evaluation of antioxidant properties. Anal. Chim. Acta, 613, 1-19. https://doi.org/10.1016/j.aca.2008.02.047

Mahdavee Khazaei, K., Jafari, S. M., Ghorbani, M., Hemmati Kakhki, A., Sarfarazi, M. (2016). Optimization of anthocyanin extraction from saffron petals with response surface methodology. Food Anal. Meth., 9, 1993-2001.

Moratalla-López, N., Bagur, M. J., Lorenzo, C., Martínez-Navarro, M. E., Salinas, M. R., Alonso, G. L. (2019). Bioactivity and bioavailability of the major metabolites of Crocus sativus L. flower. Molecules, 24, 2827. https:// doi.org/10.3390/molecules 24152827

Moyer, R. A., Hummer, K. E., Finn, C. E., Frei, B., Wrolstad, R. E. (2002). Anthocyanins, phenolics, and antioxidant capacity in diverse small fruits: Vaccinium, Rubus, and Ribes. J. Agric. Food Chem., 50, 519-525.

Østby, H., Hansen, L. D., Horn, S. J., Eijsink, V. G. H., Várnai, A. (2020). Enzymatic processing of lignocellulosic biomass: principles, recent advances and perspectives. J. Ind. Microbiol. Biotechnol.,, 47, 623-657.

Schieber, A. (2017). Side streams of plant food processing as a source of valuable compounds: Selected examples. Ann. Rev. Food Sci. Technol., 8, 97-112.

Serrano-Díaz, J., Sánchez, A. M., Maggi, L., Martínez-Tomé, M., García-Diz, L., Murcia, M. A., Alonso, G. L. (2012). Increasing the applications of Crocus sativus flowers as natural antioxidants. J. Food Sci., 77, C1162C1168.

Serrano-Díaz, J., Sánchez, A. M., Martínez-Tomé, M., Winterhalter, P., Alonso, G. L. (2013). A contribution to nutritional studies on Crocus sativus flowers and their value as food. J. Food Comp. Anal., 31, 101-108.

Singleton, V. L., Rossi, J. A. Jr (1965). Colorimetry of total phenolics with phosphomolybdic-phosphotungstic acid reagents. Am. J. Enol. Viticult., 16, 144-158.

Termentzi, A., Kokkalou, E. (2008). LC-DAD-MS (ESI+) analysis and antioxidant capacity of Crocus sativus petal extracts. Planta Med., 74, 573-581.

Tuberoso, C. I. G., Rosa, A., Montoro, P., Fenu, M. A., Pizza, C. (2016). Antioxidant activity, cytotoxic activity and metabolic profiling of juices obtained from saffron (Crocus sativus L.) floral by-products. Food Chem., 199, 18-27.

Wang, L., Wu, Y., Liu, Y., Wu, Z. (2017). Complex enzymeassisted extraction releases antioxidative phenolic compositions from guava leaves. Molecules, 22, 1648. https://doi.org/10.3390/molecules22101648

Wrolstad, R. E., Wightman, J. D., Durst, R. W. (1994). Glycosidase activity of enzyme preparations used in fruit juice processing. Food Technol., 48, 90-98. 
